\title{
Effects of Water Application Rates and Planting Density on Size Arrangements of Drip Irrigated Onions $^{1}$
}

\author{
Megh R. Goyal, Rubén Guadalupe Luna, Evangelina Recio de Hernández, \\ Luis E. Rivera, Elvin Caraballo ${ }^{2}$
}

\begin{abstract}
Onions (Var. Texas Grano 502) were drip irrigated in December 1982 at the Fortuna Agricultural Research and Development Center to evaluate the effects of water application rates (wet $=\mathrm{T} 1$, moist $=\mathrm{T} 2$ and $d r y=\mathrm{T} 3$ ) and various planting densities (S1, S2, S3 and S4) on crop performance. The evaluation characteristics were size arrangement and percentage distribution in each USDA size class, total solids percentage, defects percentage, onion volume, weight, density and commercial yield. The bulbs were significantly larger at $5 \%$ in T2 than in T1 and T3 in size classes X and XII. More than $50 \%$ of the onions were in size classes 1 to 5 and 16 to 19 , respectively. Two rows of onions on both sides of the drip line yielded significantly more at the $5 \%$ level compared with the yield of one row on both sides of the drip line. The wet treatment outyielded the dry treatment at the $5 \%$ level. The yield differences were not significant at the $5 \%$ level between wet and moist treatments. The bulbs were heavier when plant spacing was increased from $7.5 \mathrm{~cm}$ to $15 \mathrm{~cm}$.
\end{abstract}

\section{INTRODUCTION}

The consumption of fresh and processed vegetables in Puerto Rico increased from $38.6 \mathrm{~kg} /$ person in $1950-51$ to $54.5 \mathrm{~kg} /$ person in $1981-82$. The average vegetable consumption was 171.4 million $\mathrm{kg}$, consisting of $52 \%$ fresh and $42 \%$ processed vegetables during the last 8 years. Out of 11,333 hectares cultivated to vegetables in Puerto Rico, 2,166 hectares were cultivated on the south coast in 1982-83. Annual per capita consumption of onions in Puerto Rico increased from $6.1 \mathrm{~kg}$ in 1972-73 to $8.2 \mathrm{~kg}$ in $1975-76$. Puerto Rico imported 16,350 t of onions, mainly from the mainland United States in 1975-76 as against 35,754 t in 1981-82. The area planted, total onion production and the crop value were 34 hectares, 180 metric tons and $\$ 27,925$ in $1981-82$ as against 44 hectares, 251 metric tons and $\$ 313,637$ in $1982-83 .^{3}$ The climatic conditions from November through March seem to be suitable for the production of quality onions in Puerto Rico $(9,10)$.

Bleasdale (1) found that reduction in planting distance from 45 to 30

${ }^{1}$ Manuscript submitted to Editorial Board June 7, 1984.

This study was conducted under H326 (S143), Southern Region Research ProjectTrickle Irrigation in Humid Regions" and project H284 - "Grading of Vegetables."

${ }^{2}$ Associate Agricultural Engineer, Associate Horticulturist, Assistant Food Technologist, Research Assistant (Agronomy) and Research Assistant respectively, Agricultural Experiment Station, University of Puerto Rico, Mayagüez Campus, Rio Piedras, P.R.

${ }^{3}$ Dr. Héctor Medrano, personal communication, 1984. 
$\mathrm{cm}$ increased onion production by 10 to $30 \%$. Increasing the number of plants $/ \mathrm{m}^{2}$ increased the number of commercial bulbs but reduced the yield. Frappel (2) found a 10\% reduction in the yield when onions were planted in a $40 \times 40 \mathrm{~mm}$ pattern as compared to that of a 360 to $40 \mathrm{~mm}$ planting pattern. Hatridge and Bonnet (7) showed that decreasing space between plants reduced bulb size. Mangual, Ramirez and Orengo (10) encountered significant yield increases when plant spacing was varied from 90 to $30 \mathrm{~cm}$. Hall (6) indicated that $49 \%$ of the onion production in the USA was placed in storage before sale or processing and storage space was based upon onion bulk density of $640 \mathrm{~kg} / \mathrm{m}^{3}$. Goyal $(3,5)$ evaluated size arrangements of drip irrigated peppers and tomatoes. To what extent USDA grading standards $(4,8)$ may be applied to onions grown in Puerto Rico remains to be determined.

The objectives of this study were to evaluate effects of water application rates and planting density on yield, total solids, size arrangements, and fruit performance of drip irrigated onions (var. Texas Grano 502).

\section{MATERIALS AND METHODS}

This study was conducted at Fortuna Agricultural Research and Development Center, located on the semiarid southern coast of Puerto Rico. The soil belongs to the San Antón series with a $\mathrm{pH}$ of 7.9. Maximum, minimum, and average temperatures during the growing period were 16 , 32 and $25^{\circ} \mathrm{C}$, respectively. The seasonal rainfall and class A pan evaporation were 98.0 and $540.1 \mathrm{~mm}$, respectively.

The crop was subjected to three water regimes (wet, moist and dry) based upon readings of tensiometers which were installed at 15, 30 and $45 \mathrm{~cm}$ below the soil surface to control the irrigation scheduling. The main treatments were replicated six times in a randomized split-plot block design. The subtreatments were one row of onions on both sides of the chapin biwall drip line $\mathrm{e}^{4}$ at $7.5 \mathrm{~cm}$ spacing down the row ( $\mathrm{S} 1=296,296$ plants/ha); two rows of onions on both sides of the drip line at $7.5 \mathrm{~cm}$ spacing ( $\mathrm{S} 2=592,593$ plants/ha); one row of onions on both sides of the drip line at $15 \mathrm{~cm}$ spacing $\left(\mathrm{S}_{3}=148,148\right.$ plants $\left./ \mathrm{ha}\right)$; and two rows of onions on both sides of the drip line at $15 \mathrm{~cm}$ spacing $\left(\mathrm{S}_{4}=296,296\right.$ plants/ha). Plots consisted of three beds $90 \mathrm{~cm}$ apart and $12 \mathrm{~m}$ long; the center bed was harvested to obtain the experimental data.

Onion seeds (variety Texas Grano 502) were hand sown on metal flats $45 \times 30 \times 5 \mathrm{~cm}$ October 29, 1982, and the seedlings were planted in the field December 22, 1982. Dacthal W-75 was applied immediately after

\footnotetext{
${ }^{4}$ Trade names in this publication are used only to provide specific information. Mention of a trade name does not constitute a warranty of equipment or materials by the Agricultural Experiment Station of the University of Puerto Rico, nor is this mention a statement of preference over other equipment or materials.
} 
planting at the rate of $8.9 \mathrm{~kg} / \mathrm{ha}$ as a preemergent herbicide. Tok E-25 (nitrofen) at the rate of $4.5 \mathrm{~kg} / \mathrm{ha}$ was used as a postemergent herbicide. The tensiometers were installed according to "Tensiometer installation guide" by Irrometer Company, Inc., Riverside, CA. Irrigation was applied when the soil moisture tension was 50 cbars, and terminated when the moisture tension dropped to 15 cbars.

Onions were harvested April 5, 1983. After being cured for 10 days, commercial onions were counted and weighed. For determination of average bulb size, weight, volume, density and percentage loss during curing, a subsample from each subplot was taken at the time of harvest. These samples were transferred to the Food Technology Laboratory for determination of total solids, percentage of loss during curing, average bulb size, weight, volume and density. The Archimedes principle was used to determine the average bulb volume. The bulb volume was also estimated on the assumption that the onion was a perfect sphere.

\section{RESULTS AND DISCUSSION}

Table 1 indicates size arrangements of drip irrigated onions (Var. Texas Grano 502) for three water application rates $(\mathrm{T} 1=$ wet, $\mathrm{T} 2=$ moist and $\mathrm{T} 3=$ dry) in $\mathrm{S} 1, \mathrm{~S} 2, \mathrm{~S} 3$ and $\mathrm{S} 4$ plots, respectively. On weight basis, there were no significant differences at the $5 \%$ level among subtreatments and main treatments in any USDA size classes 1 to 19, except sizes 10 and 12 for T1, T2, T3; sizes 5, 9, 11, 13, 15 and 17 for S1, S2, S3 and $\mathrm{S} 4$, respectively. The moist treatment caused heavier bulbs compared with those of the wet and dry treatments, respectively, in size classes 10 and 12 . The bulbs were significantly heavier at the $5 \%$ level in subplots $\mathrm{S} 3$ compared with those of $\mathrm{S} 1$ in size class 5; in subplots $\mathrm{S} 2$ compared with those of S3 in size classes 9, 13, 15; in subplots S2 compared with those of $\mathrm{S} 1$ and $\mathrm{S} 4$ in classes 9, 15; in subplots $\mathrm{S} 4$ compared with those of $\mathrm{S} 1$ in size class 9. The total number of onions in all size classes indicated heaviest bulbs in subplots $\mathrm{S} 3$ as compared with those of $\mathrm{S} 2$ and S4.

On the basis of number of commercial bulbs, the differences were not significant at the $5 \%$ level among main treatments in all size classes and among subtreatments in size classes 1 to $4,7,10$ to 14,16 , and 19 , respectively. The number of commercial bulbs was highest at the $5 \%$ level in subplots $\mathrm{S} 3$ compared with that of $\mathrm{S} 1, \mathrm{~S} 2$ in size classes 5, 6; in subplots $\mathrm{S} 3$ compared with that of $\mathrm{S} 4$ in size class 9; in subplots $\mathrm{S} 4$ compared with that of $\mathrm{S} 2$ in size class 8 ; in subplots $\mathrm{S} 4$ compared with that of S1, S2 and S3 in size class 17; in subplots S2 compared with that of $\mathrm{S} 3$ in size classes 9, 15; in subplots $\mathrm{S} 2$ compared with that of $\mathrm{S} 1$ in size class 18 , respectively. The total number of commercial onions in all size classes was lowest at the $5 \%$ level in subplots $\mathrm{S} 3$ compared to that of $\mathrm{S} 1$ and $\mathrm{S} 2$. 
TABLE 1.-Effects of water application rates (T1, T2, T3) and planting density

(S1, S2, S3, S4) on size of drip irrigated onions (var. Texas Grano).

Date of transplanting: Dec 22, 1982. Date of last harvest: April 5, 1983

Number $(\%)$ and average weight of onions $(\mathrm{g})^{2}$

\begin{tabular}{|c|c|c|c|c|c|c|c|c|c|c|c|c|c|c|c|c|c|c|c|c|c|c|c|c|}
\hline \multirow{3}{*}{$\begin{array}{l}\text { USDA }^{1} \\
\text { bulb } \\
\text { size } \\
\text { class }\end{array}$} & \multicolumn{8}{|c|}{$\mathrm{T} 1=\mathrm{Wet}$} & \multicolumn{8}{|c|}{$\mathrm{T} 2=$ Moist } & \multicolumn{8}{|c|}{$\mathrm{T} 3=$ Dry } \\
\hline & \multicolumn{2}{|c|}{ S1 } & \multicolumn{2}{|c|}{ S2 } & \multicolumn{2}{|c|}{ S3 } & \multicolumn{2}{|c|}{ S4 } & \multicolumn{2}{|c|}{ S1 } & \multicolumn{2}{|c|}{ S2 } & \multicolumn{2}{|c|}{ S3 } & \multicolumn{2}{|r|}{ S4 } & \multicolumn{2}{|c|}{ S1 } & \multicolumn{2}{|r|}{ S2 } & \multicolumn{2}{|c|}{ \$3 } & \multicolumn{2}{|c|}{ S4 } \\
\hline & No. & $\begin{array}{c}\text { Mean } \\
\text { wt. }\end{array}$ & No. & $\begin{array}{c}\text { Mean } \\
\text { wt. }\end{array}$ & No. & $\begin{array}{c}\text { Mean } \\
\text { wt. }\end{array}$ & No. & $\begin{array}{c}\text { Mean } \\
\text { wt. }\end{array}$ & No. & $\begin{array}{c}\text { Mean } \\
\text { wt. }\end{array}$ & No. & $\begin{array}{c}\text { Mean } \\
\text { wt. }\end{array}$ & No. & $\begin{array}{c}\text { Mean } \\
\text { wt. }\end{array}$ & No. & $\begin{array}{c}\text { Mean } \\
\text { wt. }\end{array}$ & No. & $\begin{array}{c}\text { Mean } \\
\text { wt. }\end{array}$ & No. & $\begin{array}{c}\text { Mean } \\
\text { wt. }\end{array}$ & No. & $\begin{array}{c}\text { Mean } \\
\text { wt. }\end{array}$ & No. & $\begin{array}{c}\text { Mean } \\
\text { wt. }\end{array}$ \\
\hline 1 & - & - & - & - & - & - & - & - & - & - & - & - & - & - & - & - & - & - & - & - & - & - & 1 & 528.7 \\
\hline 2 & $\ldots$ & - & 1 & 527.5 & 2 & 522.1 & 1 & 576.9 & 1 & 489.9 & 1 & 446.8 & 2 & 531.3 & 1 & 554.3 & - & - & 2 & 490.7 & - & - & - & - \\
\hline 3 & 1 & 457.8 & 1 & 249.9 & 1 & 537.0 & - & - & 1 & 464.9 & 1 & 417.2 & - & - & 2 & 485.8 & 1 & 589.2 & - & - & 2 & 449.6 & - & - \\
\hline 4 & - & - & - & - & - & - & - & - & - & - & - & - & - & - & - & - & - & - & - & - & - & - & 1 & 499.9 \\
\hline 5 & $\ldots$ & - & 1 & 44.7 .4 & 3 & 525.8 & 1 & 437.0 & - & - & - & - & 3 & 477.5 & 4 & 451.3 & 1 & 430.8 & 1 & 414.1 & 1 & 432.6 & - & - \\
\hline 6 & 5 & 390.9 & 5 & 394.1 & 11 & 360.6 & 10 & 396.7 & 5 & 368.9 & 6 & 363.5 & 9 & 382.0 & 7 & 370.8 & 3 & 364.5 & 2 & 364.3 & 9 & 379.4 & 6 & 402.5 \\
\hline 7 & 4 & 318.7 & 8 & 307.8 & 3 & 300.9 & 9 & 311.6 & 5 & 309.8 & 7 & 320.1 & 11 & 310.4 & 8 & 308.2 & 9 & 339.8 & 4 & 302.1 & 8 & 336.3 & 5 & 312.5 \\
\hline 8 & 6 & 272.4 & 8 & 266.6 & 10 & 266.3 & 17 & 267.3 & 9 & 257.8 & 8 & 247.2 & 8 & 259.5 & 10 & 257.9 & 13 & 283.9 & 7 & 269.0 & 12 & 276.2 & 18 & 269.9 \\
\hline 9 & 13 & 222.4 & 19 & 231.2 & 6 & 240.2 & 14 & 216.2 & 14 & 222.3 & 13 & 226.9 & 18 & 199.7 & 8 & 229.2 & 10 & 213.1 & 12 & 229.8 & 15 & 219.1 & 7 & 209.0 \\
\hline 10 & 15 & 175.6 & 12 & 180.1 & 11 & 187.8 & 18 & 176.9 & 14 & 179.5 & 17 & 193.2 & 15 & 177.8 & 13 & 175.1 & 10 & 175.7 & 12 & 170.7 & 15 & 179.7 & 12 & 172.0 \\
\hline 11 & 14 & 130.1 & 14 & 138.3 & 15 & 137.2 & 14 & 154.0 & 10 & 148.5 & 15 & 148.5 & 18 & 130.9 & 16 & 129.2 & 15 & 114.4 & 13 & 145.3 & 12 & 133.4 & 12 & 145.5 \\
\hline 12 & 8 & 91.2 & 7 & 107.7 & 9 & 111.4 & 1 & 111.4 & 7 & 116.1 & 11 & 109.5 & 7 & 110.2 & 12 & 109.3 & 8 & 111.0 & 11 & 109.4 & 6 & 105.0 & 5 & 114.8 \\
\hline 13 & 7 & 77.2 & 10 & 89.5 & 15 & 80.3 & 6 & 87.4 & 8 & 80.9 & 9 & 82.5 & 3 & 76.9 & 9 & 74.6 & 10 & 78.7 & 14 & 85.8 & 12 & 44.1 & 9 & 86.7 \\
\hline 14 & 9 & 53.0 & 5 & 60.9 & 5 & 60.9 & 3 & 56.2 & 4 & 61.9 & 3 & 57.0 & 2 & 59.2 & 6 & 62.1 & 5 & 58.2 & 8 & 58.0 & 3 & 54.2 & 3 & 57.3 \\
\hline 15 & 12 & 40.4 & 6 & 42.2 & 3 & 44.3 & 3 & 43.1 & 8 & 44.4 & 7 & 49.1 & 2 & 44.3 & 1 & 43.0 & 12 & 47.3 & 6 & 42.7 & 2 & 45.0 & 10 & 43.7 \\
\hline 16 & 1 & 25.2 & 1 & 24.4 & 2 & 25.3 & 2 & 26.4 & 3 & 27.9 & 3 & 33.9 & 1 & 29.0 & 1 & 33.9 & 1 & 21.9 & 3 & 29.8 & 2 & 27.5 & 5 & 29.7 \\
\hline 17 & 3 & 15.7 & 2 & 16.7 & 3 & 18.4 & - & - & 1 & 16.9 & 1 & 17.1 & 1 & 18.6 & - & - & 1 & 14.3 & 2 & 16.9 & 1 & 21.6 & 5 & 18.3 \\
\hline 18 & 1 & 14.9 & - & - & - & - & 1 & 24.8 & 1 & 11.9 & - & - & - & - & 2 & 10.5 & - & - & 3 & 10.3 & - & - & - & - \\
\hline 19 & 1 & 3.4 & - & - & 1 & 6.3 & - & - & 1 & 9.3 & 1 & 5.1 & - & - & - & - & 1 & 4.8 & - & - & - & - & 1 & 11.6 \\
\hline $\begin{array}{l}\text { Sample } \\
\text { size }\end{array}$ & 29 & $\begin{array}{r}0.4 \\
4072.9\end{array}$ & 27 & 4552.3 & 21 & 3637.5 & 22 & 4310.0 & 28 & 4320.2 & 28 & $\begin{array}{r}0.1 \\
4983.3\end{array}$ & $\overline{16}$ & 3313.4 & 23 & 4242.2 & 20 & 3281.5 & 29 & 4171.6 & $\overline{17}$ & 3228.8 & 28 & 4232.6 \\
\hline $\begin{array}{l}\text { Mean } \\
\text { size, } g\end{array}$ & - & 140.4 & - & 168.6 & - & 173.2 & - & 195.9 & - & 154.3 & - & 177.9 & - & 207.1 & - & 184.4 & - & 164.0 & - & 143.8 & - & 189.9 & - & 151.2 \\
\hline
\end{tabular}

${ }^{1}$ USDA bulb size classes, $1-19$ are based on bulb diameter of $4.75,4.50,4.25,4.1875,4.125,4.00,3.75,3.50,3.25,3.00,2.75,2.50,2.25,2.00,1.75,1.50,1.25,1.00$ and 1.00 inch, respectively.

${ }^{2}$ Water application rates were based on tensiometers at 15,30 and $45 \mathrm{~cm}$ depth in the T1, T2 and T3 treatments, respectively. Subtreatments were S1 $=$ one row of onions on both sides of drip line at $7.5 \mathrm{~cm}$ spacing down the row; S2 = two rows of onions on both sides of drip line at $7.5 \mathrm{~cm}$ spacing; $\mathrm{S} 3=$ one row of onions on both sides of drip line at $15.0 \mathrm{~cm}$ spacing; and $\mathrm{S} 4=$ two rows of onions on both sides of drip line at $15.0 \mathrm{~cm}$ spacing. 
Table 2 reveals onion performance for three main treatments (T1, T2 and T3) and four subtreatments (S1, S2, S3 and S4). The variation in water application rate and plant density did not affect the percentages total solids, percentage of defective onions and onion bulk density based upon laboratory samples. The number of marketable bulbs was higher in the wet treatment at the $5 \%$ level compared with that of the moist treatment. The wet treatment outyielded the dry treatment at the $5 \%$ level. The average bulb weight was not significantly different at the $5 \%$ level in the T1, T2 and T3 plots. The number of marketable bulbs and yield were highest at the $5 \%$ level in the $\mathrm{S} 2$ plots compared with those of S1, S3 and S4 plots; in the S1 plots compared with those of S3 and S4 plots; and in the S4 plots compared with those of S3 plots, respectively. The average bulb weight was highest at the 5\% level in S3 plots compared with that of S1, S2 and S4 plots; in S4 plots compared with that of S2 plots; and in S1 plots compared with that of S2 plots, respectively. The marketable yield (t/ha) for the T1, T2 and T3 treatments, was 23.0, 22.9 and 22.2 in the S1 plots; 28.4, 24.9 and 24.5 in the S2 plots; 16.2, 15.7 and 12.9 in the S3 plots; 20.3, 16.9 and 16.6 in the S4 plots, respectively.

The average percentage total loss between April 22 and May 13, 1983, was 10.6, 10.7 and 10.2 in the wet, moist and dry treatments; and 9.5, $11.9,12.2$ and 8.3 in the $\mathrm{S} 1, \mathrm{~S} 2, \mathrm{~S} 3$ and $\mathrm{S} 4$ plots, respectively, when the onion samples were stored at ambient conditions. These values were not statistically different at the $5 \%$ level. Seasonal water applications per hectare were 288,236 and $189 \mathrm{~mm}$ for the wet, moist and dry treatments, respectively, equivalent to $28.8,23.6$ and $18.9 \mathrm{~cm}$-hectare for the wet, moist and dry treatments, respectively. Eighty-six percent of the water was applied during the first three-fourths of the growing season.

\section{RESUMEN}

En el Centro de Investigación y Desarrollo Agrícola de Fortuna se evaluó el efecto de diferentes niveles de riego (mojado-T1, hủmedo-T2, seco-T3) y la densidad de siembra (S1, S2, S3, S4) sobre el desarrollo de la cebolla var. Texas Grano 502 regada por goteo durante diciembre de 1982. Los parámetros evaluados fueron la separación por tamaño y el porcentaje de distribución en cada una de las diferentes clases (USDA), porcentaje total de sólidos, porcentaje de desechos, volumen, peso y densidad de las cebollas y rendimiento comercial. Los bulbos fueron significativamente más grandes a un nivel de $5 \%$ en el tratamiento T2 comparado con los tratamientos T1 y T3 en las clases de tamaño X y XII. Más del $50 \%$ de las cebollas estaban entre las classes 6 a 12, en contraste con menos del $5 \%$ en las clases del I al 5 y del 16 al 19 , respectivamente. El tratamiento de dos hileras de cebollas a cada lado de la línea de goteo contribuyó a un rendimiento significativamente mayor a un nivel de 5\% 
TABLE 2.-Effect of water application rates (T1, T2, T3) and planting density (S1, S2, S3, S4) on performance of drip irrigated onions (var. Texas Grano)

\begin{tabular}{|c|c|c|c|c|c|c|c|c|c|c|c|}
\hline \multicolumn{9}{|c|}{ Laboratory analysis (based on individual onions) } & \multicolumn{3}{|c|}{ Based on plot sample } \\
\hline \multirow[b]{2}{*}{$\begin{array}{l}\text { Planting } \\
\text { density }\end{array}$} & \multirow[b]{2}{*}{ Moisture } & \multirow[b]{2}{*}{$\begin{array}{c}\text { Total } \\
\text { solids } \\
\text { content }\end{array}$} & \multirow{2}{*}{$\begin{array}{c}\text { With } \\
\text { defects } \\
\text { (based } \\
\text { on } \\
\text { number) }\end{array}$} & \multicolumn{2}{|c|}{ Onion volume, $\mathrm{V}$} & \multirow[b]{2}{*}{$\begin{array}{c}\text { Average } \\
\text { bulb } \\
\text { weight }\end{array}$} & \multicolumn{2}{|c|}{ Bulk density, W/V } & \multirow[b]{2}{*}{$\begin{array}{l}\text { Marketable } \\
\text { bulbs }\end{array}$} & \multirow[b]{2}{*}{ Yield } & \multirow[b]{2}{*}{$\begin{array}{c}\text { Average } \\
\text { bulb } \\
\text { weight }\end{array}$} \\
\hline & & & & Calculated & $\begin{array}{l}\text { Displacement } \\
\text { method }\end{array}$ & & Calculated & $\begin{array}{l}\text { Displacement } \\
\text { method }\end{array}$ & & & \\
\hline Plants/ha & $\%$ & $\%$ & $\%$ & $\mathrm{~cm}^{3}$ & $\mathrm{~cm}^{3}$ & g & $\mathrm{g} / \mathrm{cm}^{3}$ & $\mathrm{~g} / \mathrm{cm}^{3}$ & No/ha & tons/ha & g \\
\hline \multicolumn{12}{|c|}{$\mathrm{T} 1=\mathrm{Wet}$} \\
\hline $\mathrm{S} 1=296,296$ & 91.82 & 8.18 & 46 & 202.6 & 220.5 & 140.4 & 0.69 & 0.64 & 135,161 & 23.018 & 170.3 \\
\hline $\mathrm{S} 2=592,592$ & 91.69 & 8.31 & 43 & 248.5 & 194.7 & 168.6 & 0.68 & 0.86 & 193,823 & 28.366 & 146.4 \\
\hline $\mathrm{S} 3=148,148$ & 91.45 & 8.55 & 43 & 253.8 & 289.2 & 173.2 & 0.68 & 0.59 & 68,989 & 16.197 & 234.8 \\
\hline $\mathrm{S} 4=296,296$ & 91.68 & 8.32 & 46 & 291.5 & 243.4 & 195.9 & 0.67 & 0.57 & 111,210 & 20.317 & 182.7 \\
\hline \multicolumn{12}{|c|}{$\mathrm{T} 2=$ Moist } \\
\hline $\mathrm{S} 1=296,296$ & 91.52 & 8.48 & 42 & 193.1 & 283.4 & 154.3 & 0.80 & 0.54 & 123,475 & 22.914 & 185.6 \\
\hline $\mathrm{S} 2=592,592$ & 91.83 & 8.17 & 37 & 242.9 & 208.9 & 177.9 & 0.73 & 0.85 & 166,154 & 24.929 & 150.0 \\
\hline $\mathrm{S} 3=148,148$ & 91.37 & 8.63 & 49 & 297.6 & 289.2 & 207.1 & 0.69 & 0.72 & 67,699 & 15.670 & 231.5 \\
\hline $\mathrm{S} 4=296,296$ & 91.88 & 8.12 & 35 & 268.9 & 260.4 & 184.4 & 0.69 & 0.71 & 92,004 & 16.947 & 184.2 \\
\hline \multicolumn{12}{|c|}{$\mathrm{T} 3=$ Dry } \\
\hline $\mathrm{S} 1=296,296$ & 91.89 & 8.11 & 44 & 227.2 & 226.2 & 164.0 & 0.72 & 0.73 & 121,574 & 22.166 & 182.33 \\
\hline $\mathrm{S} 2=592,592$ & 91.82 & 8.18 & 40 & 201.2 & 186.1 & 143.8 & 0.71 & 0.77 & 182,645 & 24.516 & 134.20 \\
\hline $\mathrm{S} 3=148,148$ & 91.43 & 8.57 & 39 & 273.0 & 251.9 & 189.9 & 0.69 & 0.75 & 61,316 & 12.862 & 209.8 \\
\hline $\mathrm{S} 4=296,296$ & 91.96 & 8.04 & 44 & 231.9 & 223.3 & 151.2 & 0.65 & 0.68 & 90,737 & 16.583 & 182.8 \\
\hline
\end{tabular}

${ }^{1}$ Water application rates were based on tensiometers at 15,30 and $45 \mathrm{~cm}$ depth in the T1, T2 and T3 treatments, respectively. Subtreatments were $\mathrm{S} 1$ = one row of onions on both sides of drip line at $7.5 \mathrm{~cm}$ spacing down the row ( $296,296 \mathrm{plants} / \mathrm{ha}) ; \mathrm{S} 2=$ two rows of onions on both sides of drip line at $7.5 \mathrm{~cm}$ spacing $(592,292$ plants/ha); $\mathrm{S} 3=$ one row of onions on both sides of drip line at $15.0 \mathrm{~cm}$ spacing ( 148,148 plants/ha); and S4 = two rows of onions on both sides of drip line at $15 \mathrm{~cm}$ spacing (296,296 plants/ha). 
comparado con el de una sola hilera a cada lado. El tratamiento mojado propició rendimientos mayores comparado con el tratamiento seco a un nivel de $5 \%$. Las diferencias en rendimiento no fueron significativas a un nivel de $5 \%$ entre los tratamientos mojado y húmedo. Los bulbos fueron más pesados cuando se aumentó la distancia de siembra de $7.5 \mathrm{~cm}$. a 15 $\mathrm{cm}$.

\section{LITERATURE CITED}

1. Bleasdale, J. K. A., 1966. The effects of plant spacing on the yield of bulb onions (Allium cepa L.) grown from seed, J. Hort. Sci. 41: 145-53.

2. Frappel, B. D., 1973. Plant spacing of onions. J. Hort. Sci. 48: 19-28.

3. Goyal, M. R., R. Guadalupe Luna, L. E. Rivera and E. R. de Hernández, 1984. Effects of plastic mulch types on crop performance of drip irrigated winter and summer peppers, J. Agric. Univ. P.R. 68 (3): 297-306.

4. Grange, G. R., 1966. US standards for grades of onions. Doc. No. 66-11545 dated Oct. 21, 1966. Department of Marketing Services, USDA, Washington, DC. Pages 6.

5. Guadalupe Luna, R., M. R. Goyal, M. Cintrón, L. E. Rivera and M. del C. Prieto de López, 1983. Effects of water application rates, plastic mulch and staking on size arrangements of mature green tomatoes under drip irrigation, J. Agric. Univ. P.R. 67 (3): 293-302.

6. Hall, C. W., 1980. Drying and Storage of Agricultural Crops, AVI Publishing Co., Inc., Westport, CT. Pages 310-59.

7. Hatridge, K. A. and J. P. Bennet, 1980. Effects of seed weight, plant density and spacing on yield responses of onion, J. Hort. Sci. 55: 247-52.

8. Magruder, R. and R. E. Wester, 1941. Storage quality of the principal American varieties of onions, Circ. 618, USDA, Washington, DC.

9. Mangual-Crespo, G. and E. Orengo-Santiago, 1981. Yield and total solids content of four onion, Allium cepa, cultivars in southern Puerto Rico, J. Agric. Univ. P.R. 65 (4): $380-84$.

10. —, C. T. Ramirez and E. Orengo, 1979. Effect of plant spacing and fertilizer levels on yield and dry bulb weight of onion cv. Texas Grano 502, J. Agric. Univ. P.R. 63 (4): $417-22$. 